\title{
The making of art islands: A comparative analysis of translocal assemblages of contemporary art and tourism
}

\author{
Solène Prince \\ School of Business and Economics, Linnaeus University, Sweden \\ European Tourism Research Institute (ETOUR), Mid-Sweden University, Sweden \\ solene.prince@miun.se (corresponding author)

\section{Meng Qu} \\ Graduate School of Humanities and Social Sciences, Hiroshima University, Japan \\ kinghoodqu@gmail.com
}

\section{Simona Zollet \\ Department of Academia-Government-Industry Collaboration, Start-up Initiatives Division, Hiroshima University, Japan \\ s.zollet@hotmail.it}

\begin{abstract}
Many small island destinations owe their spatial character to their entanglements with stakeholders involved in the arts. Space is the dynamic outcome of complex relational processes, which makes it impossible to identify a straightforward development path including when it comes to the arts and tourism. Using assemblage thinking, we scrutinize the different translocal processes influencing art-based tourism activities on Bornholm, Denmark and Naoshima, Japan. On these islands, artists, investors, residents, destination managers, creative individuals, and government officials are all involved in networks and negotiations that form complex translocal assemblages of art and tourism. The craft-artists of Bornholm took advantage of regional development policies aimed at fostering rural tourism development, and subsequently established a destination known for quality professional craftart. On Naoshima, top-down corporate investments in large-scale art developments have clashed with local stakes in rural revitalization. These top-down projects have attracted creative in-migrants who have further turned Naoshima into a hybrid space. While Bornholm's entanglement with the arts stems from the possibilities generated by its spatial evolution, Naoshima's involvement with the arts first led to reterritorialization and then creative enhancement. Both islands are, thus, distinct loci of translocal art trajectories.
\end{abstract}

Keywords: assemblage, relational geography, art-based tourism, place making, rural tourism

https://doi.org/10.24043/isj.175 • Received October 2020, Early access September 2021

(C) Island Studies Journal, 2021 


\section{Introduction}

Many small islands rely on their local culture and natural landscapes to attract tourists, rather than the 'sea, sand, and sun' brand that has turned other islands into resort destinations (Baldacchino, 2006). The tourism product of these islands often relies on symbols that are essentially rural, such as the handmade, traditional, peaceful, and natural, as opposed to the symbols of the chic urban space or standardized resort area (Prince, 2017a, 2017b). Nonetheless, engagements with extra-local processes complicate any notion of an essentially rural tourist destination (Woods, 2007, 2011). Small islands around the world have evolved into different types of spaces through their promotion of their culture, and their involvement with tourism (Cheer et al., 2017). Notably, entanglements with stakeholders in the arts have shaped the spatial character of many islands as destinations and living spaces. This is seen in investments in the arts by millionaires in places like Fogo Island, Canada (Rockett \& Ramsey, 2017) and islands of the Seto Inland Sea, Japan (Qu, 2019; Qu et al., 2020), and through the political support of artisans and artists innovations in places like the Shetland Islands, Scotland (McHattie et al., 2018) and Bornholm, Denmark (Prince, 2017a, 2017b).

Island Studies is undergoing a relational turn where its scholars increasingly recognize the multiple extra-local interconnections that shape island spaces (Pugh, 2016). Accordingly, in our exploration of island destinations and the arts, we approach space as the dynamic outcome of complex relational processes, acknowledging that there are no straightforward paths to rural development (Woods, 2011, 2007). Space finds its character through the different ways that groups of individuals react to threats and opportunities wrought by globalization (Massey, 2005). Stakeholders consistently seek to assert their interests, ensuing a power struggle over the meaning of space (Pierce et al., 2011). In this context, we ask: what forms of art interventions exist for the promotion of rural tourism development? How do artists and other relevant stakeholders respond to extra-local processes and participate in artbased tourism development?

We analyse the evolution of Naoshima, Japan and Bornholm, Denmark into art-based destinations. Using assemblage thinking, we explore some of the different translocal processes influencing the spatial character of these small islands faced with developmental issues. Assemblage thinking enables the researcher to see places as actively engaged in the reproduction of globalization, rather than mere contexts where globalization happens (Anderson \& McFarlane, 2011; Woods et al., 2021). Our focus thus lies on the situated moments of engagement and transformation that each connect Bornholm and Naoshima to the rest of the world, and which generate different spatial outcomes. Ultimately, artists, investors, residents, creative individuals, destination managers, and government officials are all involved in networks and negotiations that shape these islands into spaces of complex translocal assemblages of art and tourism. While Bornholm's entanglement with the arts stems from the possibilities generated by its spatial evolution, Naoshima's involvement with the arts led first to reterritorialization and then to creative enhancement. Both islands are, thus, distinct loci of translocal art trajectories. 


\section{Relational space, hybridity, and assemblages}

Relational geography highlights that space finds its character through active processes that interconnect people, goods, and information (Massey, 2005). Places that are traditionally considered to be rural are, thus, highly heterogeneous in light of their interplay with other places around the world. What is 'rural' is hard to demarcate and define; usually, the concept is used to mean the opposite of the urban space (i.e., less developed, connected to the past, close to nature, peaceful and spiritual settings), but much of this binary opposition reflects social imaginings rather than a concrete reality (Woods, 2011). In effect, the innovative and adaptive processes behind the spatial evolution of regions outside of urban centres are supported by a variety of extra-local factors and networks, exemplified through phenomena as diverse as lifestyle in-migration, the installation of broadband Internet, and artist residencies (Atterton, 2014; Harvey et al., 2012). Rural places are, thus, hybrids where extra-local flows challenge notions of a peripheral region decoupled from urban centres, narrowing the gap between these traditionally polarized realms (Traphagan, 2020).

Spatial complexity has forced geographers to understand places as loci of interaction where humans and non-human actants as well as organizations and technologies assemble to reproduce the global (Woods et al., 2021). Globalization is, as such, not a homogenising process that befalls upon space, but rather an expression of the stretching, intensification, and acceleration of the interactivity between and within assemblages (Woods et al., 2021). Massey (2005) sees spatial interconnections as power relations, arguing that different sets of relations will lead to different sets of threats and opportunities. This perspective sees local manifestations of globalization as "negotiation, manipulation and hybridization, conducted through but not contained by local micro-politics" (Woods, 2007, p. 487). Local actors respond to globalization through networking activities, adaptations in their value systems, and the redesign of internal structures, while seeking to take advantage of or resist external processes (Chaperon \& Bramwell, 2013). For Traphagan (2020, p. 151), hybridity exists "in the context of tension." As individuals negotiate competing cultural practices and identities, they choose from experiences and ideas that offer them a sense of stability. This process gradually creates a new coherent and cohesive place-identity based on the interactivity of dualist realms (Bhabha, 1994).

Assemblage thinking forces geographers to consider the heterogeneity, contingency, and indeterminacy of places as these are constantly renegotiated (Anderson \& McFarlane, 2011). Woods et al. (2021, p. 289) identify different spatial trajectories, proposing possibilities of "incorporation and resistance, assimilation and hybridization and ephemeral engagement and lasting change." Nonetheless, they propose a critical threshold where the durability of a place identity is tested to the point of being completely lost (Woods et al., 2021). Spatial dynamics are highly contested as different actors compete to advance their political agenda. Pierce et al. (2011) speak of 'place farming' to highlight the social and political negotiations strategically deployed to achieve particular aims. Nonetheless, while many actors may seem in disaccord, it is not impossible for them to support multiple goals and overlapping networks where interests in fact converge to create a culturally coherent and cohesive hybrid space (Pierce et al., 2011). Spatial assemblages are, thus, loci of both competition and negotiation. 


\section{Rural development and the arts}

In past decades, development strategies and discourses have highly influenced the spatial evolution of rural places. The low economic potential of these places is generally due to processes of depopulation and ageing, which in turn cause a vicious circle of diminishing access to resources and employment opportunities (Bennett, 2010). Regional development policies and programs are usually designed to encourage effective local responses - mostly in the promotion of business networks and product development - in light of the disadvantages of being situated on the periphery of urban centres (Atterton, 2014; Teraoka, 2020). Bosworth et al. (2016, p. 428) explain that this approach "offers an alternative to dualistic 'top-down' or 'bottom-up' perspectives." In this regard, many governments and action groups consider the promotion of tourism as a solution to lagging economic development (Lane, 2009). Tourism relies on the movement of people, goods, and information, bringing valuable external currency and capital to a country or region. It is consequently a major force linking places with the outside world, thus situating them in the context of modernity and globalization (Traphagan, 2020).

It has become a significant field of interest in tourism research to gain insight on the structures and potential of rural tourism to generate development in regions impacted by economic restructuring. Scholars have mostly conceptualized rural tourism as an endogenous form of tourism, as its product relies on attributes embedded in the fabric of rural places such as traditions, lifestyles, and landscapes (Lane, 2009). Rural tourism requires low levels of infrastructure and mostly depends on the small-scale entrepreneurship of people who are often new to the sector (Lane, 2009). Increasingly, it encompasses experiences beyond gazing at idyllic landscapes, such as activities related to food tourism, outdoor activities, and cultural and heritage experiences (Lane \& Kastenholz, 2015). Rural tourism also relates to the development of creative industries that deliver competitive products and experiences that enhance local attributes (Cloke, 2007). Creative industries depend on production processes that use inventiveness, imagination, skills, and talent to create wealth and jobs through the generation and exploitation of intellectual property (Richard \& Wilson, 2007).

While not all creative industries in rural areas are directed specifically at tourist consumption, they do position these places as interesting to live in and visit. The promotion of art production as a means of rural revitalization is apparent in many cases, and scholars recognize its socio-economic benefits as well as its potential to attract in-migrants and tourists (Funck \& Chang, 2018; Prince et al., 2021; Zollet \& Qu, 2019). Nonetheless, artists usually congregate in cities where art-related activities, museums, galleries, and installations can reach a wide audience (Polèse, 2012) and, as a result, chic trends, innovations, and creative industries frequently relate to the cosmopolitan urban environment. Creative industries in rural spaces are generally associated with cultural clustering embedded in spatial symbols, practices, and attributes, such as traditional products and livelihoods (Bell \& Jayne, 2010). Importantly, rural places have attributes that attract artists, leading to the development of hubs of arts and crafts in amenity-rich rural areas (Wojan et al., 2007).

What passes as 'rural' in rural tourism and amenity-rich rural communities is based in discourses, images, and relations that uphold and diffuse particular conceptions of rurality (Halfacree, 2006). Generally, rural tourism relies on idealist conceptions of the handmade, traditional, natural, peaceful, and spiritual, as opposed to the fast-paced and cosmopolitan 
character of urban spaces where its tourists mainly come from (Baylina \& Berg, 2010; Jepson \& Sharpley, 2015). These products and images mostly disregard the hybrid character of rural places and their people, and even conceal the role that tourists and tourism development play in further connecting them with urban and global processes. Traphagan (2020, p. 170) argues that, in such cases, actors such as local citizens and government officials "balance nostalgic renderings of the area's [...] past with modern structures related to the political economies of historical preservation and tourism." The rural space as a lived space for its inhabitants ultimately differs from the perceived space in the imagination of outsiders such as tourists (Halfacree, 2006). Many actors thus find themselves balancing their dual roles as residents of a space outside urban centres and as producers of idyllic rurality in their engagements with tourists (Daugstad, 2008). Nonetheless, the arts can serve to redefine rurality by offering a way for visitors to engage critically with rural spaces and its people. Many art projects exist to defy preconceptions of rurality (Crawshaw \& Gkartzios, 2016; Waitt \& Gibson, 2013). Such creative endeavours are important community capacity-building strategies, and they demonstrate that the arts can benefit social sustainability in rural communities (AnwarMcHenry et al., 2018).

Not all places engage with the arts to develop social projects or a place-based or traditionally rural tourist product. Contemporary art museums and installations, established through public and/or private funding, have been strategically located outside of major urban centres to provide a solution to regional economic decline - one that involves attracting tourists to consume world-renowned art. This top-down strategy is a long way from the policies and programs championing effective local responses. These processes are not without controversy, often causing conflicts over the meaning of 'space' as it is co-opted by art which is disembedded from the place (Bain \& Landau, 2019; Franklin, 2018). This is evident in Japan, where many large-scale art projects, such as festivals and facilities, have been set up with the aim of revitalizing economically declining regions ( $\mathrm{Qu}, 2019$; $\mathrm{Qu}$ et al., 2020). The image of rurality projected in such spaces is one of nostalgia, where art serves to reconnect urban populations with scenery and traditions of a past, simpler life (Klien, 2010). However, these rural spaces are highly hybridized (Klien, 2010; Tagore-Erwin, 2018).

Top-down approaches to art-based tourism can lead to what Mitchell (2013) calls 'creative destruction', which refers to a shift from a primary- and secondary-based rural economy towards leisure-oriented activities such as tourism, often driven by large-scale investors seeking new opportunities for capital accumulation. This, in turn, potentially leads to processes of deterritorialization as a new place identity emerges as a result of a complete destabilization of initial identity by external forces (Woods et al., 2021). As creative destruction unsettles local livelihoods, 'creative enhancement' (Mitchell, 2013) is a more desirable process, occurring when rural places acquire a multi-functional character in which new economic activities and functions do not displace the existing ones. In this case, opportunities for multiplicity and new trajectories are slowly increased to materialize as assemblages of urban-rural and local-global reproductions that stabilize new cultural identities (Woods et al., 2021). 


\section{Methodology}

Hay (2006) notes that scholars should seek to understand islands as socially experienced in order to capture the multitude of interactions and practices behind island place making. Islands have acquired many identities through their embroilment in extra-local processes that contest their specificity and isolation (Hay, 2006; Pugh, 2016). In our comparative analysis, we focus on the situated moments of engagement and transformation that connect Bornholm, Denmark and Naoshima, Japan to the rest of the world. The first case relates to a cluster of craft-artists and the second to the development of contemporary art facilities and installations.

\subsection{Bornholm}

The data from Bornholm comes from fieldwork carried out in 2013 and 2014, during which the lead author interviewed 19 of the 64 craft-artists who were members of the local Arts and Crafts Association Bornholm (ACAB) at that time, including the two founding members. The interviews took place in the workshops, boutiques, and homes of these craft-artists. The study also included interviews with two key actors in the promotion of the arts and tourism on Bornholm: the director of the Bornholm Art Museum (who is also a member of the jury determining $\mathrm{ACAB}$ membership), and an officer at Destination Bornholm, the island's official destination management association. On both occasions, the fieldwork took place in the autumn because it is then that the tourist season winds down on Bornholm, leaving time for craft-artists and other stakeholders to participate in interviews. However, the tourist season is not completely over in autumn, thus making it possible to gather first-hand observations at local galleries, museums, boutiques, and events before most of them closed in winter. The time in the field also enabled the attendance of European Ceramic Context 2014, part of a biennial symposium for European contemporary glass and ceramics held on Bornholm.

\subsection{Naoshima}

The data from Naoshima comes from fieldwork conducted between 2016 and 2019. The second author conducted 18 semi-structured interviews during the tourist season in 2019 . He interviewed 15 of the 73 small businesses run by newcomers, long-term residents, and commuters. These interviews include owners of creative studios and art facilities, but also stakeholders involved in industries such as agriculture and food processing and services such as transportation, retail, accommodations, and restoration. Interviews with stakeholders in the public sector included two island government officials responsible for tourism planning and development, and an official of the local tourism association. One manager and two employees of the Benesse Corporation also participated in interviews. While we use the umbrella term 'Benesse Corporation' here, we are aware that this entity includes multiple legal representative bodies, including Benesse Art Site Naoshima, Naoshima Cultural Village, Naoshima Fukutake Art Museum Foundation, and Benesse Holdings. The manager is responsible for the development of major art projects and sites on the island such as the Chichu Art Museum, the Art House Project, and the Benesse House Museum. Since the Benesse Corporation restricts their employee's liberty of doing interviews, the Benesse employee interviews took place outside working hours, in an unofficial capacity. The second author also collected data through extensive participant observation, which he carried out through several visits to Naoshima during and after its tourist season, including during the 2016 and 
2019 art festival seasons. The second author also gathered data by working as a tour organizer with a private tour agency. With this company, he guided four educational tours on Naoshima in 2019.

\section{Craft-art on Bornholm}

Bornholm is an island in the Baltic Sea with a population of just over 39,500 inhabitants (Statistics Denmark, 2020). Though its population is now stabilizing after many years of decline, Bornholm still experiences youth out-migration. As a result, 30\% of the population is over 65 years of age (Statistics Denmark, 2020), and the island faces the structural challenges associated with a declining economy and population (Broegaard, 2020). The island has undergone major economic restructuring in recent years, starting in the 1990s when several European and national programs were implemented to intervene in the island's laggard economy (Bornholms Regionskommune, 2012). The local fishing industry nearly collapsed in the 1980s, just as the last ceramic factories of the island shut down their operations (Hofer, 2009). Economic restructuring that aimed to stimulate tourism led to the development of various micro-businesses involved mostly with specialized foods, hospitality, and handcrafts, which now characterize Bornholm's economy and rural destination brand (Ioannides \& Petersen, 2003; Manniche \& Larsen, 2013). The island has also evolved into a worldrenowned hub for craft-art (Broegaard \& Feldthus Andersen, 2018). These developments have encouraged growing mobility and migration, and, as a result, many residents display multiple place attachments and engage in translocal networks (Broegaard, 2020).

The island is a popular tourist destination for Danes and other Europeans. During its short summer tourist season, Bornholm hosts over half a million tourists yearly who come for its beaches, picturesque villages, biking trails, countryside, and food and drink culture (Bornholms Regionskommune, 2012). The micro-businesses of Bornholm have been the object of many studies in regional development (see Broegaard, 2020; Ioannides \& Petersen, 2003; Manniche \& Larsen, 2013). They frame Bornholm as a realm of lifestyle enterprises where creative individuals engage in place making activities through their networking and innovative thinking.

\subsection{From the factory to the art-studio}

Clay has linked Bornholm to extra-local flows and processes for centuries. The tradition of ceramics on Bornholm dates back to the Middle Ages, when its clay pits would provide the material to create various pottery items to sell around the Baltic Sea region. Important ceramic design factories, such as the Hjorth and Søholm factories, appeared in the mid-1800s. These factories employed artisans who reproduced designs by hand to sell and export. In the 1930s, two of Hjorth's daughters established their own ceramic studio in the town of Gudhjem, contributing to the emergence of the craft-art movement in Denmark. The global spread of this movement dates back to the 1800 s, caused by uneasiness with the alienating and standardizing forces of globalization in industrialized countries (Koplos \& Metcalf, 2010). Here, the stretching, intensification, and acceleration of interactions between places and people can be seen both as an ill and as a solution to those ills. The craft-art movement led to the studio-art movement, where craftspeople retreated to studios with materials such as clay, glass, metal, wood, and textile to perfect the form, aesthetic, and technique of their 
creations. On Bornholm, ceramic factories have disappeared or turned into museums, and several small private studios have flourished instead. Importantly, this focus on localized activities has entangled Bornholm in new translocal assemblages, rather than led to its disconnection from the rest of the world.

In the 1960s, Bornholm was attractive to artists because of low house prices and the presence of tourists. This initiated the clustering of hundreds of ceramicists on Bornholm. Globally, craft-art was becoming more commercialized as artists professionalized their work, balancing artistic presentation with reliable business practices (Koplos \& Metcalf, 2010). This also affected the craft-artists on Bornholm. In an interview, the director of the art museum on Bornholm explained that the development of glass art on the island stems from the entrepreneurial activities of a Danish businessperson in the '70s who sought to boost local tourism. His ambitions served to turn old fishing-era smoke houses into glass-blowing studios. Eventually, the innovation gained attention, and there are now a dozen glass studios on Bornholm. With the popularity of glass-art came a need for assistant glassblowers. This need, along with the popularity of ceramics on the island, led to the establishment of a school to train designers in craft-art, which eventually became the Danish School of Design for glass and ceramics. Craft-art on Bornholm is, thus, greatly shaped by outside influences such as global trends in the commercialization of art, the standardization of education, prices on the housing market, international tourist flows, and creative in-migration.

In the early 2000s, a few key players initiated the creation of an association that would enable craft-artists on Bornholm to take advantage of the tourist season for economic purposes. The development of the arts and craft cluster was garnering attention from local politicians who were seeking to boost tourism on Bornholm. Various sources of funding were available to promote regional development through tourism, and, as a result, local politicians decided to brand each of the island's municipalities with their own focus. There was interest in branding the Hasle municipality as a centre for craft-art. This sparked the grassroots formation of the Arts and Crafts Association Bornholm (ACAB) in 2002, as two local craftswomen realized that the island's craft-artist community would benefit most from these political initiatives if it presented itself as a unified interest group (Hofer, 2009). Currently, the $\mathrm{ACAB}$ has some 70 members.

Initially, the $\mathrm{ACAB}$ secured 3 million euros from their regional and federal governments, along with additional funds through the European Union's LEADER Plus program and the European Social Fund (Hofer, 2009). They used this money to make themselves visible on the island, online, and in visitor information. They opened Grønbechs Gård, Bornholm’s Centre for Crafts, to display their art to tourists. Ideally, upon discovering appealing craft-art there, tourists would then visit artists or one of the many local boutiques to buy craft-art. The ACAB financed courses for its members to help them improve their skills at tasks such as accounting and web design. Later, they secured funds to travel to national and international exhibitions and to go on study trips. The ACAB equipped itself with a secretary whose task is to identify opportunities for its members and help them secure the funding needed to realize their artistic ambition. The members of the ACAB are active players in the international craft-art scene, as their network enables them to cross local boundaries and participate in global art trends. Craft-art on Bornholm is, therefore, not just an assemblage of processes and actants reproducing an island space; it also contributes to the production of other places around the world. 


\subsection{Professional art in idyllic rurality}

The ACAB confers agency to craft-artists to frame Bornholm as a cultural destination and as a global hub for quality arts and crafts. In 2017, the World Craft Council Europe granted Bornholm the title of 'World Craft Region', earned in light of its high diversity, quality, and density of craftspeople, and its many museums and institutions related to arts and crafts (Broegaard \& Feldthus Andersen, 2018). However, during fieldwork, it arose that the local destination management organization sought mainly to attract families with children who could enjoy the island's natural areas. While the island is deeply embedded in translocal networks of craft-art, images of idyllic rurality and trends in rural tourism are pervasive to its place identity (see Figure 1). Interestingly, the activities and ambitions of ACAB members unfold in both contrast and harmony with these images and practices.

Primarily, the ACAB assures that the craft-art produced on Bornholm will be of global artistic quality, rather than a place-based cultural product. ACAB membership entails going through a strict application process, which involves sending a portfolio to an independent jury for examination. The jury, consisting of three respected members of the arts scene in Denmark, look at the professional quality of the craft, its uniqueness, and ensure that the applicant resides permanently on Bornholm. Making the ACAB jury external was strategic; it serves to preserve unity within the association, preventing internal frictions over matters such as taste during the selection of candidates. Incidentally, it also serves to promote an aesthetic that overrides the insular cultural boundaries. During fieldwork, craft-artists were understood to have found inspiration for their art in multiple sources located beyond Bornholm, for instance during art-residences, field trips, and visits abroad. Three ceramicists spoke of art residencies in China when explaining the designs behind their creations. Another ceramicist had been inspired by foliage in India to create shapes and colours on her creations. For artists, travels abroad are crucial not just for artistic inspiration, but also for finding supplies, markets, audiences, and for networking with like-minded individuals (Harvey et al., 2012). Bornholm, by being home to individuals with professional artistic ambitions, becomes a hybrid combination of global cultures and universal principles materializing in art studios located in its small fishing villages and countryside towns.

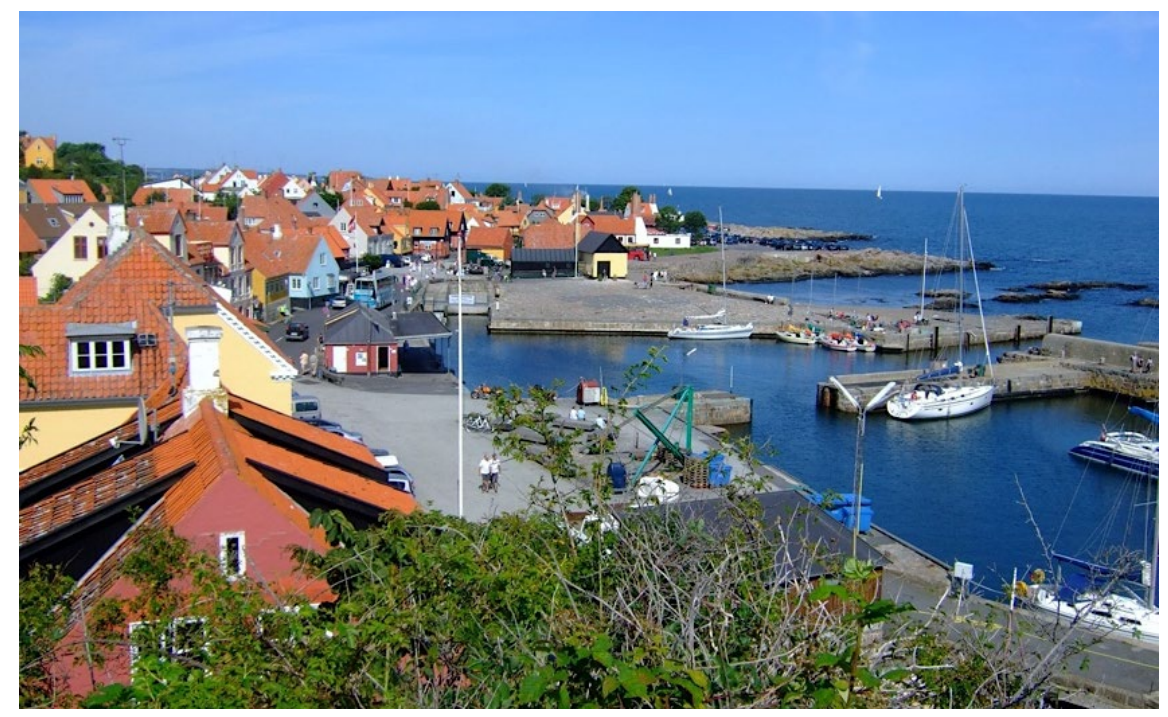

Figure 1: The town of Gudhjem is popular with tourists because of its many specialized boutiques selling products from Bornholm, including craft-art. Source: Solène Prince, 2014. 
Nonetheless, craft-artists reproduce a space where professional art can co-exist with a typically rural culture. Mostly, craft-art on Bornholm relates to the rural idyll of Denmark because many craft-artists see a connection between the search for an experience of rurality and the consumption of their crafts. In interviews, the craft-artists agreed that the tourists interested in buying their crafts were interested in acquiring something handmade on the island during their visit. A number of craft-artists mentioned getting recurring customers who are just as interested in a friendly chat as they are in buying. Arguably, this interest in craftart relates to stereotypical conceptions of rural places as locations for unique, handmade, and small-scale production. One ceramicist explained this as follows:

They can go to many other places to buy cheap and sometimes really nice things. But, I think here it is a story. We are making it from the start, we decide how it should look, how we are making it, fire it [in the kiln] and then sell it. Mostly, it is not possible. So many people are involved in making a thing; making a bit, sending it [down the production line], making a bit, and sending it [further down the production line]. So, I think the craft is done in one of the last places where we are making everything from start to finish.

As already explored, the studios of these craft-artists are translocal assemblages where global trends, cultures, and processes are reproduced. They are, nonetheless, viewed as harbouring resistance to chains of mass production and standardised consumption, which for many individuals is the ugly face of globalization. Craft-artists embrace rural tourism and the discourses of rurality at its foundation as, through it, they can foster a type of interaction that helps them preserve values that are important to them as professional artists, such as integrity.

As Broegaard (2020) notes, Bornholm has become a place of multiple place attachments and translocal networks through the activities of its entrepreneurial community. The same applies to the activities of the craft-artists. No craft on Bornholm is purely rural or local; materials are mostly imported, few artists are originally from the island, and they all reproduce their designs to some extent. Some craft-artists use assistants in their workshops or have their crafts reproduced in factories in Poland and China, for example. Others are uncomfortable with this practice and prefer to reproduce their successful designs with their own hands. Many craft-artists work part-time at other jobs or have seasonal jobs in order to secure a steady income while pursuing their art. Certain craft-artists would like more support to advance their business skills in accounting, sales and pricing, marketing, and grant application. However, business consultation does not always cater to the specific needs of craft-artists who are primarily interested in advancing their art form and reputation as artists (Broegaard \& Feldthus Andersen, 2018). These practices and attitudes demonstrate some of the tensions behind rural development through the arts, where many artist enterprises do not fully adhere to conventional business logic. The global is, thus, reproduced in different ways and with varying levels of success within the art studios on the island, often depending on individual interpretations of success. 


\section{Rural revitalization on Naoshima}

Naoshima belongs to the Kagawa prefecture of Japan and is located between the islands of Honshu and Shikoku in the Seto Inland Sea. It is also situated within the largest national park of Japan, the Setonaikai National Park. Naoshima owes much of its economic development in the $20^{\text {th }}$ century to heavy manufacturing industries. In 1917, Mitsubishi Material Corporation established smelting and refinery operations on the island. These operations are still active and represent a major source of local employment. Similar to other islands in the Seto Inland Sea, Naoshima faces severe out-migration and an ageing population (Qu, 2019), with $35 \%$ of the island's population being over 65 years of age. Naoshima's population has decreased by 30\% in the last 25 years (Statistics Bureau of Japan, 2017), and there are currently around 3,050 inhabitants (Naoshima Town, 2020).

In the 1990s, investments from millionaire Soichiro Fukutake and his Benesse Corporation led to the development of contemporary art facilities and installations on Naoshima and other islands of the Seto Inland Sea. This art currently attracts a considerable number of visitors in the region; Naoshima receives on average half a million tourists per year (Naoshima Tourism Association, 2019). Researchers have followed the transformation of Naoshima into a space for the consumption of contemporary art, observing the emergence of opportunities for further tourism development (Funck et al., 2013; Shimizu \& Sakai, 2016) and for community revitalization (Funck \& Chang, 2018). At the same time, these researchers have noted dissatisfaction amongst residents who felt little connection, interest, and benefit from these art sites and installations. Ultimately, place making activities on Naoshima are generally framed in relation to contemporary art development and creative in-migration for rural revitalization and tourism development purposes.

\subsection{The corporate art island}

The organization of contemporary art festivals and community projects has become popular in Japan as a result of a rural revitalization movement centred on using the arts to counter depopulation and economic decline in remote areas. This socially engaged and mostly rural art movement encourages human exchange and interaction among different interest groups and individuals involved in affected areas, often inviting its participants and viewers to reflect on issues of sustainability in their engagement with art (Klien, 2010). Favell (2015) remarks that these projects come in stark contrast to the commercial pop art of urban Japan because place-based attributes and typical rural issues take centre stage in the creation of art.

Naoshima is highly involved in the contemporary art movement unfolding in declining areas of Japan, resulting in a continuous blurring of the line between the urban and rural character of the island. This involvement also creates tensions around the purpose of art-based tourism for rural revitalization. The activities that led to the evolution of art-based tourism on Naoshima date back to the establishment of the Naoshima International Campsite in 1989, which displayed sculptures and installations for the enjoyment of its guests (Benesse Art Site, 2015). In 1992, this campsite became the Benesse House: a contemporary art museum with permanent collections and temporary exhibitions from Japanese and international artists. The Benesse House (see Figure 2) is one of many activities of the Benesse Art Site Naoshima organization. Benesse Holdings and the Fukutake Foundation are its financial bodies, all belonging to Soichiro Fukutake. Through this corporation, Fukutake promotes the 
development of art sites and museums on Naoshima and other islands of the Seto Inland Sea, such as Inujima and Teshima (Benesse Art Site, 2015). Benesse Art Site Naoshima endowed Naoshima with the label of 'art island' as it extended its patronage of the arts beyond the walls of the museum (Favell, 2015). Its commissioned art now features in the landscape of Naoshima, such as the pumpkin sculptures of Japanese artist Yayoi Kusama. Between 1997 and 1999, the Art House Project led to the installation of artworks in local buildings and public spaces. Naoshima also saw the opening of the Chi-Chu Art Museum in 2004, and became a site for the activities of the Setouchi Triennial art festival in 2010.

The newly acquired 'art island' identity highlights a process of reterritorialization, as outsiders such as Fukutake and other businesspeople and artists, mostly from urban centres, continuously work to endow Naoshima with new meaning. In interviews it was clear that, for many long-term residents, the development of contemporary art installations and museums has led to a loss of identity — an identity that relates to the rural as a lived space. This lived reality contrasts with the goals of the organization, stated on its official webpage as seeking to "create significant spaces by bringing contemporary art and architecture in resonance with the pristine nature of the Seto Inland Sea, a landscape with a rich cultural and historical fabric" (Benesse Art Site Naoshima, 2020). Particularly, for many residents, the contemporary art projects show little compatibility with the island way of life, based on the proximity with the sea. Arguably, this top-down process reproduces rural spaces through the lens of urban perceptions, where urban notions of the rural (i.e., in need of development, a playground for urbanites, pristine nature and rich cultural heritage) drive forward place framing and, ultimately, place making.

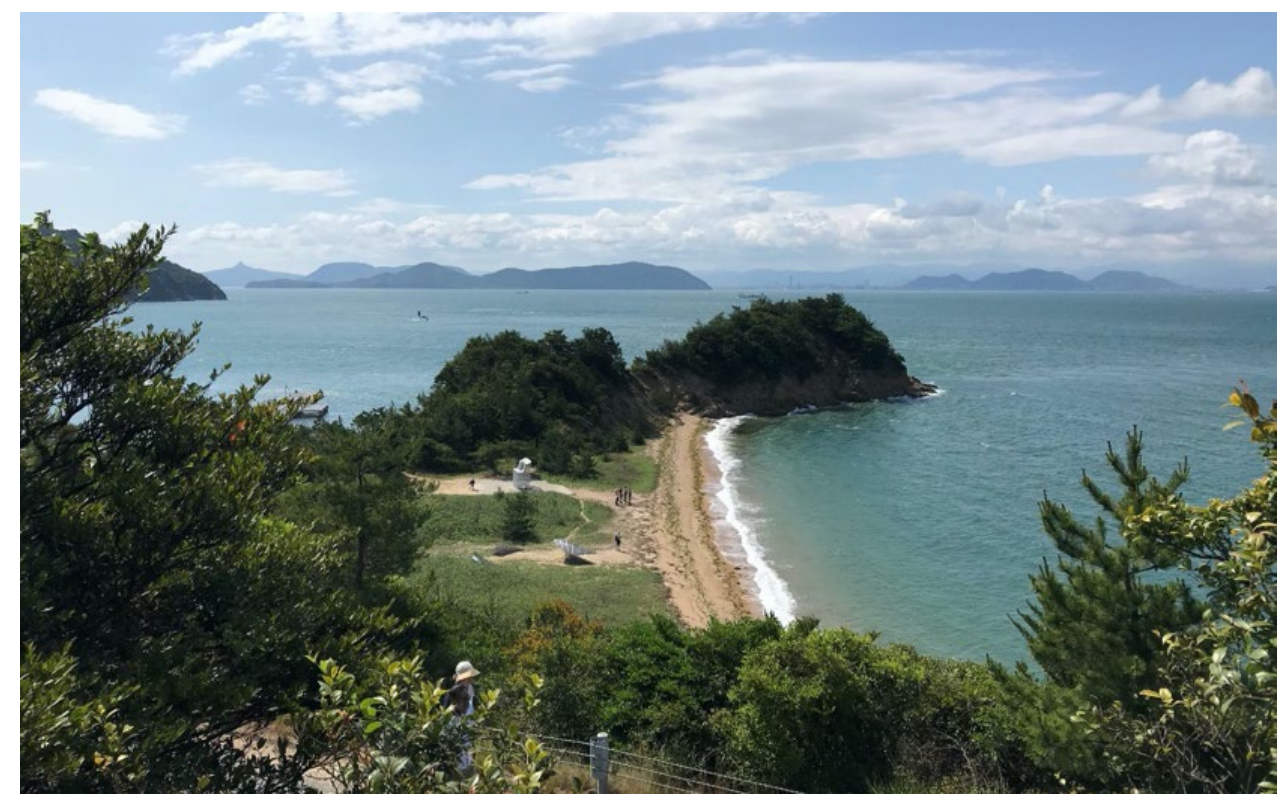

Figure 2: The view from Benesse House reveals Naoshima's idyllic character. Source: Meng Qu, 2020.

Naoshima is enmeshed in national interventionist discourses that frame remote areas with declining populations as needing help from outside. Here, the rural is a space that external actors want to impact, rather than inhabit. During an interview, a Benesse House spokesperson maintained the corporation's belief that major private stakeholders are crucial 
to regional development - in this case, through their ability to assemble high-profile artworks and manage their promotion. Arguably, residents could not have secured themselves such impressive collections. The idea is that corporate support should benefit the local population first through the development of spaces that they themselves can enjoy, and then from the influx of tourists for economic development. In this regard, the Benesse representative referred to the "Naoshima method" envisioned by Fukutake (see Fukutake \& Kitagawa, 2016):

The idea of regional revitalization that we are thinking of is not about increasing the number of tourists and becoming famous, but to set a very simple goal, which is to encourage the local people first. We had a good reputation overseas [with this approach], and we have called it the 'Naoshima Method' for quite some time.

Naoshima as a translocal assemblage of art and tourism is, thus, an experimental ground for place making strategies within a global context of population decline and ageing, but also of neoliberal patronage of the arts and the longing for an idyllic past. The Benesse Corporation emphasizes that their core mission is to improve local quality of life, and many of their projects signal this interest. However, despite the Benesse Corporation's claim of working for the island community, tourism development arguably occupies a central role in the corporation's agenda, as shown by the many tourists that the Benesse art sites attract every year. The interviews revealed that the Benesse Corporation's actual engagement in social affairs is perceived by some residents to be minor. Benesse officials and residents thus hold different views of what it means to promote art for the sake of community prosperity.

Corporate patronage of the arts has put Naoshima on the national and global map of art-based destinations. Ironically, the service infrastructure necessary to host large numbers of visitors is counterproductive to the production of an essentially idyllic rural space to consume art. The urbanizing effects of tourism on Naoshima were apparent during fieldwork. Informants showed concern over the influx of tourists as it caused social frictions, crowding, and noise, especially around the artworks. The increase in tourists caused a loss of sense of security among some long-term residents, with some noting the bad manners of tourists and that they have been known to enter gardens and homes. These are issues typically associated with urban spaces, in contrast to the stereotypical peace, quiet, and friendliness usually attributed to places with low population densities. It also is clear that there is a need for sound tourism planning and visitor management strategies on Naoshima; processes that will draw new actants into the assemblage, such as government officials, consultants, tourism researchers, and planners, as well as signs, busses, barriers, and other material elements of the application of rules and regulations. This, however, will ultimately continue to reinforce the identity of the island as a tourist destination.

\subsection{Creative trajectories}

The art stakeholders and the island's residents play different roles in the formation of Naoshima as a translocal assemblage of contemporary art and tourism. The artists whose art is displayed on the island are mostly temporary residents, only present to create their art or conduct social projects. These individuals still live highly cosmopolitan lives by moving from place to place to make and exhibit art and to network with like-minded individuals. This 
creates a dual trajectory where the development of the arts on Naoshima has its own history juxtaposed with the history of the long-term residents of the island. The interviews revealed that, for long-term residents, the local economy still relies mainly on the Mitsubishi factory, as the Benesse projects and facilities do not provide them with employment. The Benesse Corporation usually recruits employees under three-year contracts and these individuals are usually from other parts of Japan, sometimes even from overseas. As such, it rarely provides art management jobs to long-term residents, while the short-term employment opportunities at the Benesse facilities do not contribute to population retention. Overall, non-tourismrelated business owners do not really perceive any benefit from Benesse art development.

Where the trajectory of the long-term residents does meet with translocal processes of art-based tourism to create a new identity for the island is in the flourishing of a creative business atmosphere. The art of the Benesse Corporation has led to the creation of a diversified tourist space on Naoshima, as it encouraged migrants in search of a rural lifestyle to establish themselves and start businesses on the island. During the last 15 years, over 100 new, small tourism-oriented businesses have flourished on Naoshima, where there was originally none. The high-profile art installations have endowed Naoshima with a reputation as an ideal space to engage in creative and entrepreneurial activities. In this context, longterm residents have also taken advantage of the tourism influx, with some - including previous employees at the Mitsubishi factory - opening restaurants, accommodations, and bicycle rental businesses. Urban-to-rural migrants are more likely to establish fancy cafés and guesthouses, often incorporating elements of contemporary design in their operations to adhere to the 'art island' character. In-migrants also include creative people such as artists and designers who moved to Naoshima to open art studios, further reproducing a chic atmosphere on the island. As anthropologists have observed (Klien, 2020; Traphagan, 2020), this entrepreneurialism fuses elements of urban lifestyles (i.e., working long hours, using social media for marketing, ordering goods online) and extra-local cultures (i.e., serving international cuisine and coffee, decorating with travel memorabilia) with place-based elements to create a hybrid space.

The small businesses flourishing on Naoshima due to its reputation as an 'art island' contribute to the reproduction of post-growth rural space. Naoshima is no longer solely an industrial space; it also caters to desires for creative entrepreneurialism and new lifestyle experiences outside of urban corporate environments. These new spatial dynamics are reproduced on Naoshima through the various networks forming among long-term residents and newcomers. Lifestyle enterprises depend on interpersonal relationships, volunteerism, and local knowledge exchange to function (Broegaard, 2020). Some creative in-migrants mix their tourism activities with art education and use their talent to generate social innovations for the island community. These activities reinforce social bonds and, as such, create opportunities for revitalization on Naoshima. However, interviews revealed the difficulties that some newcomers face in socially integrating into the community. For instance, many in-migrants operating a creative business on Naoshima commute from nearby cities like Okayama and Takamatsu. These types of entrepreneurs usually establish a satellite business on Naoshima with financing from urban-based investors. Those that we spoke to mentioned having difficulties finding suitable housing and office space on the island, remaining mostly outsiders to its social fabric as a result. This movement of people, capital, money, and ideas stretches, 
intensifies, and accelerates Naoshima's connection to the rest of Japan and even the world meanwhile, tensions arise and negotiations are needed to create a new internal social fabric.

\section{Discussion and conclusions}

Bornholm and Naoshima both owe their spatial character as destinations for the enjoyment and consumption of art and rural experiences to their distinct reproductions of global processes. Just as much as contemporary art can only exist through human and material interactions and the exchange of ideas, so is tourism also fundamentally based on the movement of people, goods, and information. Any engagement with the two will force one to look outwards rather than inward. With our two cases, we have outlined a number of different responses to the globalizing processes of art and tourism. As Woods et al. (2021, p. 289) propose, there is "incorporation and resistance, assimilation and hybridization and ephemeral engagement and lasting change." On Bornholm and Naoshima, most artists come from outside, but have left different traces of themselves; from fleeting encounters during festivals and temporary exhibits, to permanent change by integrating the social fabric with their own art-studios. Both islands are hybrid spaces where a new cultural identity has emerged through the interactivity of dualist realms (Bhabha, 1994).

Ultimately, these two islands are distinct spaces that have materialized in very different ways, though both as translocal assemblages of art and tourism. These differences highlight the complexity, continuity, and multiplicity of spatial assemblages (Anderson \& McFarlane, 2011). On Bornholm, the adoption of the practices and ideology of the studio-art movement clearly connects the island to global discourses, urban in-migration, and artist translocal networks, which challenges any notion of this island being essentially rural. However, when adapted to the island's context, the reproduction of the studio-art movement on Bornholm serves to resist some of the perceived nasty sides of globalization, such as standardization and alienation, thus providing an opportunity to celebrate and reproduce aspects of the rural idyll such as handmade quality craft-art produced in a small, personalized space where the artists behind the creation can be met in person. This incorporation of the rural idyll in daily interactions highlights the blurriness behind the rural space as lived and imagined (Daugstad, 2008). At the destination level, stakeholders continue to promote an image of nature and family experiences in its tourist material. Nonetheless, as Pierce et al. (2011) argue, multiple goals and overlapping networks can converge to create a culturally coherent and cohesive space. The craft-artists of Bornholm have found a way to negotiate their place within the imagery and discourses of rural tourism, both as a networked cluster and in their individual encounters with tourists - as have many of the other small businesses that have emerged to offer hybrid cultural and natural products on the island. The creation of their professional association is an example of micro-politics deployed to adapt and manipulate globalization to one's advantage (Woods, 2007).

While Bornholm's entanglement with craft-art stems from the possibilities generated by its spatial evolution from a place for the production of factory houseware to one for studio art, Naoshima's involvement with the arts materializes in a first instance as reterritorialization. There is no connection with the landscape of contemporary art facilities and installations around Naoshima and the history of fishery and heavy manufacturing that previously defined its spatial evolution. These large-scale and externally financed projects cannot be analysed in 
isolation from the larger phenomenon in Japan of using contemporary art to counter the socio-economic decline of remote areas. This trend has made the corporate patronage of the art on Naoshima possible. Moreover, this line of trajectory coincides with the emergence of a post-growth Japan, where urbanites seek a creative lifestyle away from the corporate urban environment (Klien, 2020). Naoshima thus unfolds as a place for art-based tourism focused on contemporary installations, but also for small-scale, often creative, entrepreneurialism, attesting to a process of creative enhancement following one of 'creative destruction', to use the words of Mitchell (2013). The new space is not without its internal tensions, but it does show signs of a new coherent and cohesive identity based in hybridity.

The notion of the rural as an imagined realm created through the diffusion of essentially rural images, symbols, and discourses is also significant (Halfacree, 2006). The Benesse Corporation is a powerful actor framing Naoshima as an essentially rural space, especially by speaking of its 'pristine nature' and 'rich cultural fabric' in its promotional material. The activities and perceptions of the artists, visitors, in-migrants, and long-term residents on Naoshima are continuously influenced by such discourses as they either embrace or resist a situated engagement with the island as a typically rural space. While the art financed by the Benesse Corporation should celebrate typically rural landscapes and cultures, ironically, it accelerates and intensifies the connection of the island with global processes such as artist mobilities, the dissemination of contemporary design, mass tourism, and urban-to-rural migration, which all work towards its urbanization and modern translocal character. As Traphagan (2020) argues, nostalgic renderings of the past can be combined with modern structures of the political economy, such as tourism development, for strategic purposes.

We have sought to present Bornholm and Naoshima as sites of continuously productive activity and unfolding multiple possibilities. On both islands, artists, investors, residents, creative individuals, destination managers, and government officials are all involved in networks and negotiations that shape these islands into two different spaces of complex translocal assemblages of contemporary art and tourism. As assemblages, they are hybrid spaces where the line between what is essentially rural and urban, as well as local and global, is blurred through their intensive interactions with extra-local people, ideas, materials, capital, investments, discourses, and processes. These two islands are different, but, in the end, they are both loci for translocal art trajectories. On both Bornholm and Naoshima, the global is simultaneously embraced, adapted, resisted, and negotiated in the multiple situated engagements with the arts, tourism, and creative entrepreneurialism of the various actants involved on and with these islands. Knowing these islands from the inside helps us understand their complex exteriority, and thus, like Pugh (2016) and Hay (2006), we also advocate more research that seeks to establish the spatial relations behind the distinct character of islands.

\section{References}

Anderson, B., \& McFarlane, C. (2011). Assemblage and geography. Area, 43(2), 124-127. https://doi.org/10.1111/j.1475-4762.2011.01004.x

Anwar-McHenry, J., Carmichael, A., \& McHenry, M. P. (2018). The social impact of a regional community contemporary dance program in rural and remote Western Australia. Journal of Rural Studies, 63, 240-250. http://doi.org/10.1016/j.jrurstud.2017.06.011 
Atterton, J. (2014). Invigorating the new rural economy: Entrepreneurship and innovation. In M. Shucksmith \& L. D. Brown (Eds.), Routledge international handbook of rural studies (pp. 165-180). Routledge.

Bain, A. L., \& Landau, F. (2019). Artists, temporality, and the governance of collaborative place making. Urban Affairs Review, 55(2), 405-427. https://doi.org/10.1177/1078087417711044

Baylina, M., \& Berg, N. G. (2010). Selling the countryside: Representations of rurality in Norway and Spain. European Urban and Regional Studies, 17(3), 277-292. https://doi.org/10.1177\%2F0969776409356215

Bell, D., \& Jayne, M. (2010). The creative countryside: Policy and practice in the UK rural cultural economy. Journal of Rural Studies, 26(3), 209-218. https://doi.org/10.1016/j.jrurstud.2010.01.001

Benesse Art Site. (2015). Becoming: Benesse Art Site Naoshima (2nd ed.). Fukutake Foundation. Benesse Art Site Naoshima. (2020). About the Islands - Benesse Art Site Naoshima. Retrieved August 1, 2020, from http://benesse-artsite.jp/en/about/island.html

Bennett, D. (2010). Creative migration: A Western Australian case study of creative artists. Australian Geographer, 41(1),

117-128.

https://doi.org/10.1080/00049180903535626

Bhabha, H. (1994). The location of culture. Routledge.

Bornholms Regionskommune. (2012). Udveklingsplan. Retrieved September 8, 2021, from https://www.brk.dk/IndflydelsePolitik/Planer/Documents/BUP/BUP forslag hjemmeside.pdf

Bosworth, G., Annibal, I., Carroll, T., Price, L., Sellick, J., \& Shepherd, J. (2016). Empowering local action through neo-endogenous development: The case of LEADER in England. Sociologia Ruralis, 56(3), 427-449. https://doi.org/10.1111/soru.12089

Broegaard, R. B. (2020). Rural destination development contributions by outdoor tourism actors: A Bornholm case study. Tourism Geographies, Advance online publication. https://doi.org/10.1080/14616688.2020.1795708

Broegaard, R. B., \& Feldthus Andersen, L. (2018). World Craft Region - Titlen som aktiv for Bornholms kunsthåndverk og turisme - Hovedrapport. CTR.

Chaperon, S., \& Bramwell, B. (2013). Dependency and agency in peripheral tourism development. Annals of Tourism Research, 40, 132-154. https://doi.org/10.1016/j.annals.2012.08.003

Cheer, J. M., Cole, S., Reeves, K. J., \& Kato, K. (2017). Tourism and islandscapes: Cultural realignment, social-ecological resilience and change. Shima, 11(1), 40-54. http://doi.org/10.21463/shima.11.1.07

Cloke, P. (2007). Creativity and tourism in rural environments. In G. Richards \& J. Wilson (Eds.), Tourism, creativity and development (pp. 37-47). Routledge.

Crawshaw, J., \& Gkartzios, M. (2016). Getting to know the island: Artistic experiments in rural community development. Journal of Rural Studies, 43, 134-144. https://doi.org/10.1016/j.jrurstud.2015.12.007

Daugstad, K. (2008). Negotiating landscape in rural tourism. Annals of Tourism Research, 35(2), 402-426. https://doi.org/10.1016/j.annals.2007.10.001 
Favell, A. (2015). Islands for life: Artistic responses to remote social polarization and population decline in Japan. In S. Assman (Ed.), Sustainability in contemporary rural Japan (pp. 135-150). Routledge.

Franklin, A. (2018). Art tourism: A new field for tourist studies. Tourist Studies, 18(4), 399416. https://doi.org/10.1177\%2F1468797618815025

Fukutake, S., \& Kitagawa, F. (2016).

[From Naoshima to the Setouchi International Art Festival: Art has changed an area]. Gendaikikakushitsu.

Funck, C., \& Chang, N. (2018). Island in transition: Tourists, volunteers and migrants attracted by an art-based revitalization project in the Seto Inland Sea. In D. K. Mueller \& M. Więckowski (Eds.), Tourism in transitions: Recovering decline, managing change (pp. 81-96). Springer.

Funck, C., Otsuka, H., \& Chang, N. (2013). アート・ツーリズムにもとづく発展の可 能性と課題: 直島の事例から [Chances and problems of development based on art tourism: The example of Naoshima]. Studies of Environmental Sciences, 8, 77-90. https://doi.org/http://doi.org/10.15027/35655

Halfacree, K. (2006). Rural space: Constructing a three-fold architecture. In P. Cloke, T. Marsden, \& P. Mooney (Eds.), The handbook of rural studies (pp. 44-62). Sage.

Harvey, D. C., Hawkins, H., \& Thomas, N. J. (2012). Thinking creative clusters beyond the city: People, places and networks. Geoforum, 43(3), 529-539. https://doi.org/10.1016/j.geoforum.2011.11.010

Hay, P. (2006). A phenomenology of islands. Island Studies Journal, 1(1), 19-42.

Hofer, V. (2009). Bornholm: The isle of artisans. In H. Gögl \& C. Schedler (Eds.), Big strategies for small business: Exceptional projects in Europe (pp. 97-130). Palgrave Macmillan.

Ioannides, D., \& Petersen, T. (2003). Tourism 'non-entrepreneurship' in peripheral destinations: A case study of small and medium tourism enterprises on Bornholm, Denmark. Tourism Geographies, 5(4), 408-435. https://doi.org/10.1080/1461668032000129146

Jepson, D., \& Sharpley, R. (2015). More than sense of place? Exploring the emotional dimension of rural tourism experiences. Journal of Sustainable Tourism, 23(8-9), 11571178. https://doi.org/10.1080/09669582.2014.953543

Klien, S. (2020). Urban migrants in rural Japan: Between agency and anomie in a post-growth society. Suny Press.

Klien, S. (2010). Contemporary art and regional revitalisation: Selected artworks in the Echigo-Tsumari Art Triennial 2000-6. Japan Forum, 22(3-4), 513-543. https://doi.org/10.1080/09555803.2010.533641

Koplos, J., \& Metcalf, B. (2010). Makers: A history of American studio craft. University of North Carolina Press.

Lane, B. (2009). Rural tourism: An overview. In T. Jamal \& M. Robinson (Eds.), The Sage handbook of tourism studies (pp. 354-370). Sage.

Lane, B., \& Kastenholz, E. (2015). Rural tourism: The evolution of practice and research approaches-towards a new generation concept? Journal of Sustainable Tourism, 23(8-9), 1133-1156. https://doi.org/10.1080/09669582.2015.1083997 
Manniche, J., \& Larsen, K. T. (2013). Experience staging and symbolic knowledge: The case of Bornholm culinary products. European Urban and Regional Studies, 20(4), 401-416. https://doi.org/10.1177\%2F0969776412453146

Massey, D. (2005). For space. Sage.

McHattie, L. S., Champion, K., \& Broadley, C. (2018). Craft, textiles, and cultural assets in the Northern Isles: Innovation from tradition in the Shetland Islands. Island Studies Journal, 13(2), 39-54. https://doi.org/10.24043/isj.47

Mitchell, C. J. A. (2013). Creative destruction or creative enhancement? Understanding the transformation of rural spaces. Journal of Rural Studies, 32, 375-387. https://doi.org/10.1016/j.jrurstud.2013.09.005

Naoshima Tourism Association. (2019). Naoshima Tourism Travel Site. Retrieved June 6, 2020, from http://www.naoshima.net

Naoshima Town. (2020). Population of Naoshima. Retrieved June 6, 2020, from http://www.town.naoshima.lg.jp/smph/government/gaiyo/toukei/jinnkou20191113 $\underline{\text { html }}$

Pierce, J., Martin, D. G., \& Murphy, J. T. (2011). Relational place-making: The networked politics of place. Transactions of the Institute of British Geographers, 36(1), 54-70. https://doi.org/10.1111/j.1475-5661.2010.00411.x

Polèse, M. (2012). The arts and local economic development: Can a strong arts presence uplift local economies? A study of 135 Canadian cities. Urban Studies, 49(8), 18111835. https://doi.org/10.1177\%2F0042098011422574

Prince, S. (2017a). Craft-art in the Danish countryside: Reconciling a lifestyle, livelihood and artistic career through rural tourism. Journal of Tourism and Cultural Change, 15(4), 339358. https://doi.org/10.1080/14766825.2016.1154064

Prince, S. (2017b). Rural authenticity and agency on a cold-water island: Perspectives of contemporary craft-artists on Bornholm, Denmark. Shima, 11(1), 102-121. https://shimajournal.org/issues/v11n1/j.-Prince-Shima-v11n1.pdf

Prince, S., Petridou, E., \& Ioannides, D. (2021). Art worlds in the periphery: Creativity and networking in rural Scandinavia. In K. Scherf (Ed.), Creative tourism and sustainable development in smaller communities (pp. 259-282). University of Calgary Press.

Pugh, J. (2016). The relational turn in island geographies: Bringing together island, sea and ship relations and the case of the Landship. Social \& Cultural Geography, 17(8), 10401059. https://doi.org/10.1080/14649365.2016.1147064

$\mathrm{Qu}$, M. (2019). Art interventions on Japanese islands: The promise and pitfalls of artistic interpretations of community. The International Journal of Social, Political and Community Agendas in the Arts, 14(3), 19-38. https://doi.org/10.18848/23269960/CGP/v14i03/19-38

Qu, M., McCormick, A. D., \& Funck, C. (2020). Community resourcefulness and partnerships in rural tourism. Journal of Sustainable Tourism, Advance online publication. https://doi.org/10.1080/09669582.2020.1849233

Rockett, J., \& Ramsey, D. (2017). Resident perceptions of rural tourism development: The case of Fogo Island and Change Islands, Newfoundland, Canada. Journal of Tourism and Cultural Change, 15(4), 299-318. https://doi.org/10.1080/14766825.2016.1150287 
Shimizu, R, \& Sakai, T. (2016). アートサイト直島にみる社会的広域圏形成プロセス の展開 [Expansion of the Wide Social formation Process Seen in Art Site Naoshima; Ātosaito Naoshima ni miru shakai-teki kōiki-ken keisei purosesu no tenkai]. 都市政策 研究 [Urban Policy Research; Toshi seisaku kenkyū], 18, 127-141.

Statistics Bureau of Japan. (2017). Population census. Retrieved September 10, 2021, from http://www.stat.go.jp/english/data/kokusei/index.htm

Statistics Denmark. (2020). Population in Denmark. Retrieved September 10, 2021, from https://www.dst.dk/en/Statistik/emner/befolkning-og-valg/befolkning-ogbefolkningsfremskrivning/folketal

Tagore-Erwin, E. (2018). Contemporary Japanese art: Between globalization and localization. Arts and the Market, 8(2), 137-151. http://doi.org/10.1108/aam-04-2017-0008

Teraoka, S. (2020). Mobility turn in rural districts in Japan: From "Kankō (tourism)" to "Kankei (relationships)". In H. Endo (Ed.), Understanding tourism mobilities in Japan (pp. 73-86). Routledge.

Traphagan, J. W. (2020). Cosmopolitan rurality, depopulation, and entrepreneurial ecosystems in 21st-century Japan. Cambria Press.

Waitt, G., \& Gibson, C. (2013). The Spiral Gallery: Non-market creativity and belonging in an Australian country town. Journal of Rural Studies, 30, 75-85. http://dx.doi.org/10.1016/j.jrurstud.2012.12.003

Wojan, T. R., Lambert, D. M., \& McGranahan, D. A. (2007). The emergence of rural artistic havens: A first look. Agricultural and Resource Economics Review, 36(1), 53-70. http://dx.doi.org/10.22004/ag.econ.10158

Woods, M. (2011). Rural. Routledge.

Woods, M. (2007). Engaging the global countryside: Globalization, hybridity and the reconstitution of rural place. Progress in Human Geography, 31(4), 485-507. http://dx.doi.org/10.1177/0309132507079503

Woods, M., Fois, F., Heley, J., Jones, L., Onyeahialam, A., Saville, S., \& Welsh, M. (2021). Assemblage, place and globalisation. Transactions of the Institute of British Geographers, 46(2), 284-298. http://dx.doi.org/10.13039/100011199

Zollet, S., \& Qu, M. (2019). The role of domestic in-migrants for the revitalization of marginal island communities in the Seto Inland Sea of Japan (Migration in Remote and Rural Areas [MIRRA] Research and Policy Briefs Series). Rural Policy Learning Commons. http://rplc-capr.ca/wp-content/uploads/2019/09/MIRRABrief.Zollet.Qu .pdf 